\title{
Student Perceptions Related to Physical Education Online Learning During Covid-19 Pandemic
}

\author{
Mochamad Ridwan ${ }^{1, *}$ Agidia Dwi Veronika Saputri ${ }^{2,}$ Ira Pratiwi $^{3,}$ Veranda Putri \\ Cahyaningtias $^{4}$ \\ 1,2,3,4 Department of Physical Education, Universitas Negeri Surabaya, Indonesia \\ *Corresponding author. Email: mochamadridwan@unesa.ac.id
}

\begin{abstract}
Online learning has many views from all students, so it is necessary to know how students perceive it. This study aims to see the perception of students related to online learning of physical education. The author uses non-experimentation with a quantitative descriptive approach — subjects who have sampled as many as 35 students, with sampling techniques, namely cluster random sampling. The research place is National Senior High School in West Java. The study results were that students experienced internet network constraints of $80 \%$ due to uneven connections in each region. As many as $94.3 \%$ of students were easier to learn in the classroom by interacting directly with teachers. The limitation of this research is that few students are willing to fill out the questionnaire that has been distributed. This study concludes that students get help and support from schools and the government to carry out the online learning process.
\end{abstract}

Keywords: Online learning, Perceptions, Physical education, Network, Students.

\section{INTRODUCTION}

Physical education is an educational program that can improve the development and growth of every child. Physical education can be done in all forms of training in the right and appropriate way so that the goals of the learning program are achieved. One of the main intervention strategies in physical education is to improve cardiorespiratory, improve adolescent health and muscle fitness [1]. Physical education includes three aspects of assessment, including attitude, knowledge, and skills. Aspects of skills in physical education learning involve physical movement, so solid physical conditions are needed in physical education learning. Applying or building high-quality physical education is very important because it can provide students with appropriate behavior, confidence, and skills. According to [2], motor skills development should not be ignored because of its association with physical activity. Increased physical activity in physical education plays an essential role in forming an active lifestyle for children [3]. The existence of current pandemic conditions can affect the ongoing learning process that is less effective because of changes during the learning process that were implemented initially face-to-face. Still, with a pandemic, conditions must be done online.
Of course, in the process of teaching and learning, one must experience changes in terms of motivation because, in learning to teach online, it is easy to feel bored and saturated with the atmosphere. The teacher's creativity in modifying learning is needed so that students are interested and enthusiastic in following the learning process. Considering physical education as integral to education, we should encourage adolescents to take their free time to move to achieve a healthier quality of life [4]. Moreover, in modern times as it is today, sports are not only done in school, but we can do sports activities anywhere and anytime. Public facilities are made by the government for the prosperity of the community in utilizing it. Therefore, to increase physical activity, there must be will or motivation [5]. A learning process can be said to be successful or achieve the target of the learning plan must have fulfilled various aspects. One of the factors supporting the success of learning is support or motivation. Motivation is an essential aspect of each individual's drive to perform actions or learn [6]. Motivation is critical to support the learning process because having high motivation can affect the learning outcomes. In addition to supporting success, motivation also aims to increase the sense of a job or activity carried out. The impact of motivation is fatigue on mental that will affect an actor's performance [7]. Motivation 
significantly impacts a process that is carried out, both in the learning process and other activities. Before doing a strategy, there must be an effect to be more maximal in carrying out the process. During the learning process, teacher motivation is the most crucial thing because motivation includes the professionalism that must be owned by a teacher to teach [8].

Physical education is a subject that requires high motivation because physical education includes topics that are done outside the classroom and use physical activity. The purpose of physical education learning is as a sensory-motor stimulus to develop motor skills carried out in a school environment with safe and harmless facilities [3]. But not all students like a movement activity or physical education, so the level of motivation of each student is also different. Therefore, in physical education learning, there is a high innovation so that the atmosphere and the learning process are not dull and student motivation is very high. A study states that reason can be influenced by way of teaching according to the curriculum that has been established so that student motivation is affected by the learning [9]. Inspiration comes from two factors: internal factors and external factors. Internal factors are support that comes purely from within the individual so that only himself can control because these factors come from their own will.

In contrast, external factors are support that comes from outside themselves or from various outside environments. The school environment can be from teachers or friends, family environment based on research that has been done by [10]. Physical education learning in the Covid-19 Pandemic was conducted entirely online. In contrast, the authors conducted a study where schools showed physical education learning in a hybrid manner; $50 \%$ of students followed the teaching and learning process offline and 50\% online. However, there is a study presented by [11] that the procedure in conducting online learning is to use various methods that can be used as a platform in the delivery of materials in the online learning process, following the percentage of response rates from multiple platforms: face-to-face (100\% response), PowerPoint appearance (86.11\% response), assignment (78.89\% response), video impressions (68.89\% response), and PDF files (61.11\% responses). This study aims to find out the perception of students related to online physical education subjects.

\section{METHODS}

The research used is non-experimental with a quantitative descriptive approach. The population in this study was 48 students - subjects who have sampled as many as 35 students, with sampling techniques, namely cluster random sampling. The research place is National Senior High School in West Java. Data analysis techniques used are descriptive analysis using descriptive statistical calculation percentages. This research instrument consists of a student perception questionnaire composed of 26 statement items, each given a choice of strongly agree, agree, disagree, and strongly disagree spread through a google form. The questionnaire data is processed, analyzed, and interpreted with the help of SPSS version 21. The questionnaire used has been tested for validity with a sign $<0.05$ and reliability test results of 0.905 .

\section{RESULTS}

This study used statements with a score range of 1 4. This statement is analyzed based on answers strongly agreed (SA), agreed (A), disagreed (DA), and strongly disagreed (SDA), after which the percentage is calculated. Technical indicators discuss the internet signal and the ability of students to perform activities that use internet access. There are four statements in this indicator; the signal sub-indicator gives a response that tends to be negative, where almost all or precisely $80 \%$ of responders say they often experience signal-related constraints during online-based learning. While from the internet's proficient sub-indicators obtained a positive response. This shows that technical rules related to internet signals on online learning are still experienced by students. But students' ability to operate the internet is good because it gives a positive response of $60 \%$, and $68.8 \%$ of students already understand accessing online learning. Details of this data can be seen in Table 1 .

Table 1. Recapitulation of student response on technical indicators

\begin{tabular}{|c|c|c|c|c|c|}
\hline $\begin{array}{c}\text { Sub } \\
\text { Indicator }\end{array}$ & Statement & SA & A & DA & SDA \\
\hline \multirow[t]{2}{*}{ Signal } & $\begin{array}{l}\text { I often experience } \\
\text { difficulties related } \\
\text { to the internet } \\
\text { signal I use. }\end{array}$ & $28.6 \%$ & $51.4 \%$ & $20 \%$ & $0 \%$ \\
\hline & $\begin{array}{l}\text { I am interested in } \\
\text { learning online } \\
\text { because the } \\
\text { internet signal in } \\
\text { my area is } \\
\text { smooth. }\end{array}$ & $8.6 \%$ & $17.1 \%$ & $68.6 \%$ & $5.7 \%$ \\
\hline \multirow[t]{2}{*}{$\begin{array}{l}\text { Proficient } \\
\text { internet }\end{array}$} & $\begin{array}{l}\text { I'm good at using } \\
\text { the internet. }\end{array}$ & $11.4 \%$ & $48.6 \%$ & $40 \%$ & $0 \%$ \\
\hline & $\begin{array}{l}\text { I understand how } \\
\text { to access online } \\
\text { learning }\end{array}$ & $8.6 \%$ & $60 \%$ & $25.7 \%$ & $5.7 \%$ \\
\hline
\end{tabular}

The learning process is divided into three subindicators, namely interaction, tasks, and teaching materials. These three things are things that teachers prepare in online-based learning. Teachers need to ensure that interactions occur, adequate teaching materials, and evaluation through tasks. The criteria in this learning process are the independence of wisdom and understanding of students. Although done online, communication between students and teachers continues 
to run well. This is evidenced by a percentage of $71.4 \%$. At the time of the online learning pandemic, the interest of students studying in the classroom with teachers was huge, with a share of $94.3 \%$.

Table 2. Recapitulation of Student Response on Interaction Sub-Indicator Learning Process Indicators

\begin{tabular}{|l|l|c|c|c|c|}
\hline \multicolumn{1}{|c|}{$\begin{array}{c}\text { Sub } \\
\text { Indicator }\end{array}$} & \multicolumn{1}{|c|}{ Statement } & SA & A & DA & SDA \\
\hline $\begin{array}{l}\text { Self } \\
\text { sufficient }\end{array}$ & $\begin{array}{l}\text { Communication } \\
\text { between teachers } \\
\text { and students can } \\
\text { go well. }\end{array}$ & $14.3 \%$ & $57.1 \%$ & $25.7 \%$ & $2.9 \%$ \\
\cline { 2 - 5 } & $\begin{array}{l}\text { Real-time } \\
\text { discussions make } \\
\text { it easy for me to } \\
\text { see the teacher's } \\
\text { response. }\end{array}$ & $22.9 \%$ & $54.3 \%$ & $22.9 \%$ & $0 \%$ \\
\hline $\begin{array}{l}\text { Under } \\
\text { standing }\end{array}$ & $\begin{array}{l}\text { I can understand } \\
\text { the material } \\
\text { through } \\
\text { discussion. }\end{array}$ & $17.1 \%$ & $48.6 \%$ & $34.3 \%$ & $0 \%$ \\
\cline { 2 - 6 } & $\begin{array}{l}\text { I'm more } \\
\text { interested in } \\
\text { studying in the } \\
\text { classroom because } \\
\text { I can interact } \\
\text { directly with } \\
\text { teachers. }\end{array}$ & $60 \%$ & $34.3 \%$ & $5.7 \%$ & $0 \%$ \\
\hline
\end{tabular}

In the learning process indicator sub-indicator task comprehension criteria, students give a negative response. As much as $82.8 \%$ of teachers give too many tasks so that students understand less than optimal because students do not understand then in the work of their duties have not been maximal. Furthermore, the functions given so far by teachers were done individually by students, and only a few who asked for answers to other colleagues and students experienced the pressure of $62.9 \%$. In detail, the recap of student response results can be seen in the following.

Table 3. Recapitulation of student response on task subindicator learning process indicator

\begin{tabular}{|c|c|c|c|c|c|}
\hline $\begin{array}{c}\text { Sub } \\
\text { Indicators }\end{array}$ & Statement & SA & $\mathbf{A}$ & DA & SDA \\
\hline \multirow[t]{2}{*}{$\begin{array}{l}\text { Under } \\
\text { standing }\end{array}$} & $\begin{array}{l}\text { The task given } \\
\text { is so much, I } \\
\text { have difficulty } \\
\text { understanding } \\
\text { the material. }\end{array}$ & $37.1 \%$ & $45.7 \%$ & $17.1 \%$ & $0 \%$ \\
\hline & $\begin{array}{l}\text { I can } \\
\text { understand the } \\
\text { material so that } \\
\text { I make the task } \\
\text { to the } \\
\text { maximum }\end{array}$ & $14.3 \%$ & $34.3 \%$ & $51.4 \%$ & $0 \%$ \\
\hline \multirow[t]{3}{*}{$\begin{array}{l}\text { Self- } \\
\text { sufficient }\end{array}$} & $\begin{array}{l}\text { I do my job } \\
\text { independently. }\end{array}$ & $14.3 \%$ & $74.3 \%$ & $8.6 \%$ & $2.9 \%$ \\
\hline & $\begin{array}{l}\text { I asked my } \\
\text { colleague for } \\
\text { answers, then I } \\
\text { revised. }\end{array}$ & $2.9 \%$ & $14.3 \%$ & $74.3 \%$ & $8.6 \%$ \\
\hline & $\begin{array}{l}\text { I was depressed } \\
\text { that the task } \\
\text { was given too } \\
\text { much for online } \\
\text { lessons, not } \\
\text { independently. }\end{array}$ & $20 \%$ & $42.9 \%$ & $37.1 \%$ & $0 \%$ \\
\hline
\end{tabular}

The student's response to the next sub-indicator is teaching material. In the independent criteria, half the number of students do not read teaching materials even though students have read teaching materials that have been given by teachers. Still, students do not understand the fabric with a percentage of $80 \%$. On the criteria of understanding of $71 \%$ of students understand the teaching material more quickly in videos, with the model being the teacher himself. But students are easier to take videos from other sources with $85.7 \%$ presentations. In detail, the recap of the results of the student response on the criteria of teaching materials can be seen in Table 4 below.

Table 4. Recapitulation of Student Response on Learning Process Indicators Sub Indicators of teaching materials

\begin{tabular}{|c|c|c|c|c|c|}
\hline $\begin{array}{c}\text { Sub } \\
\text { Indicators }\end{array}$ & Statement & SA & A & DA & SDA \\
\hline \multirow[t]{2}{*}{$\begin{array}{l}\text { Self- } \\
\text { sufficient }\end{array}$} & $\begin{array}{l}\text { I often don't } \\
\text { read teaching } \\
\text { materials. }\end{array}$ & $2.9 \%$ & $48.6 \%$ & $48.6 \%$ & $0 \%$ \\
\hline & $\begin{array}{l}\text { I have read the } \\
\text { teaching } \\
\text { material but do } \\
\text { not understand } \\
\text { the material } \\
\text { given }\end{array}$ & $20 \%$ & $60 \%$ & $20 \%$ & $0 \%$ \\
\hline \multirow[t]{2}{*}{$\begin{array}{l}\text { Under } \\
\text { standing }\end{array}$} & $\begin{array}{l}\text { I better } \\
\text { understand the } \\
\text { teaching } \\
\text { materials in the } \\
\text { form of learning } \\
\text { videos made by } \\
\text { my teachers. }\end{array}$ & $14.3 \%$ & $57.1 \%$ & $28.6 \%$ & $0 \%$ \\
\hline & $\begin{array}{l}\text { I better } \\
\text { understand the } \\
\text { teaching } \\
\text { materials taken } \\
\text { from other } \\
\text { sources. }\end{array}$ & $8.6 \%$ & $77.1 \%$ & $11.4 \%$ & $2.9 \%$ \\
\hline
\end{tabular}

Three external parties are seen on the support indicator, namely the government, schools, and student guardians. Support is provided based on the criteria of providing facilities and training. As many as $85.7 \%$ of students have known the government's home study application to facilitate online learning. A total of $65.7 \%$ of students agree that the government has supported online learning and has understood the role of government, including providing training in online learning. However, many students already know the tools but can not operate them as much as $85.7 \%$. In detail, this response to government support can be seen in Table 5 .

Table 5. Recapitulation of student response on Government Sub-Indicator Support Indicators

\begin{tabular}{|c|l|c|c|c|c|}
\hline $\begin{array}{c}\text { Sub } \\
\text { Indicator }\end{array}$ & \multicolumn{1}{|c|}{ Statement } & SA & A & DA & SDA \\
\hline Facilities & $\begin{array}{l}\text { I know of an } \\
\text { online learning } \\
\text { app created by } \\
\text { the government }\end{array}$ & $8.6 \%$ & $77.1 \%$ & $11.4 \%$ & $2.9 \%$ \\
\hline
\end{tabular}




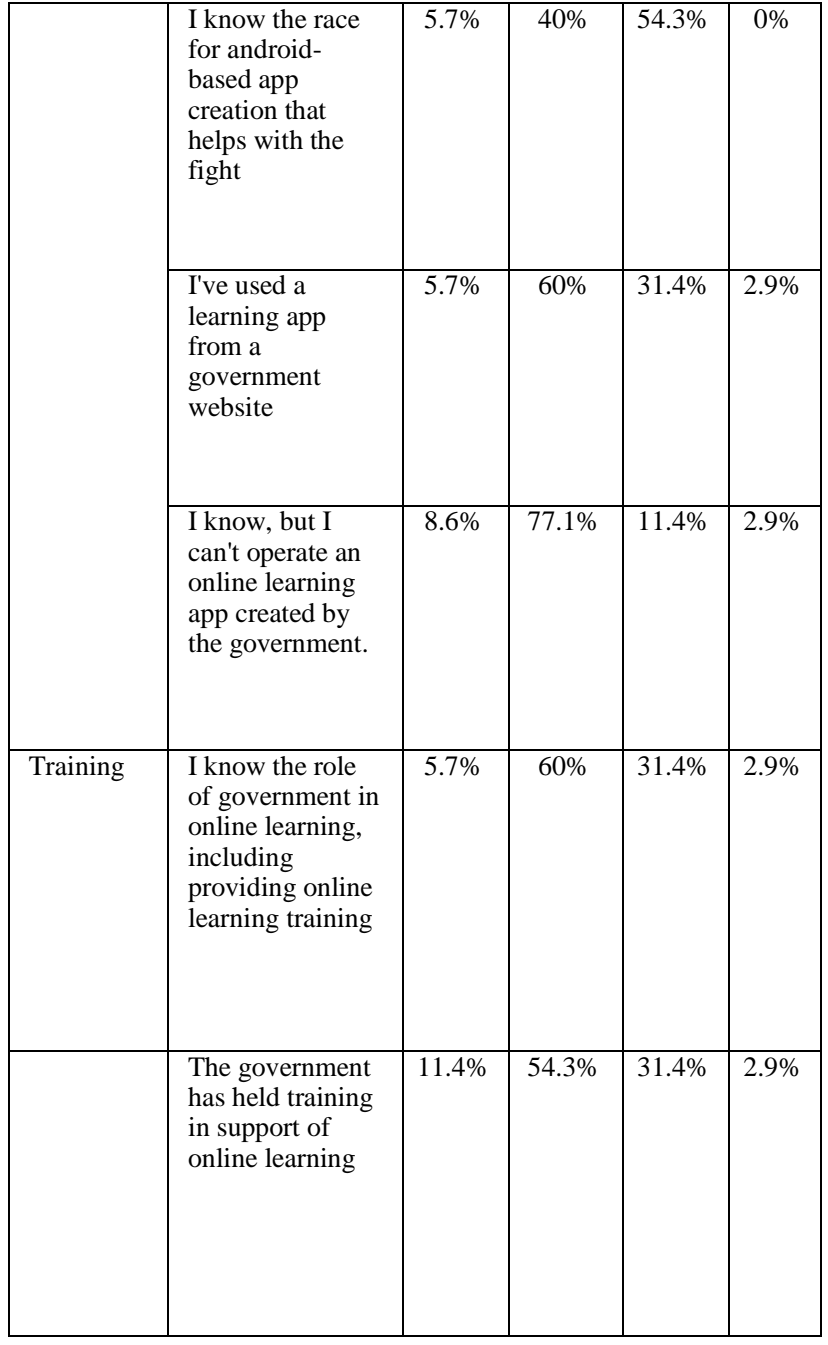

The student's response to support from the school tends to be positive; this can be seen in Table 6 . Statements given to students give a positive response from both facility and training criteria. $85.7 \%$ of students agree that the school has provided online learning training. A total of $77.2 \%$ of students agreed that the school provides facilities for online learning. And schools already have an in-network learning system.

Table 6. Recapitulation of Student Response on Training Indicators

\begin{tabular}{|c|l|c|c|c|c|}
\hline $\begin{array}{c}\text { Sub } \\
\text { Indicator }\end{array}$ & \multicolumn{1}{|c|}{ Statement } & SA & A & DA & SDA \\
\hline Training & $\begin{array}{l}\text { Schools provide } \\
\text { training on online } \\
\text { learning }\end{array}$ & $17.1 \%$ & $68.6 \%$ & $14.3 \%$ & $0 \%$ \\
\cline { 2 - 6 } & $\begin{array}{l}\text { Schools provide } \\
\text { facilities to } \\
\text { students for online } \\
\text { learning. }\end{array}$ & $14.3 \%$ & $60 \%$ & $25.7 \%$ & $0 \%$ \\
\hline Facilities & $\begin{array}{l}\text { The school } \\
\text { already has an } \\
\text { online-based } \\
\text { learning system. }\end{array}$ & $14.3 \%$ & $62.9 \%$ & $22.9 \%$ & $0 \%$ \\
\hline
\end{tabular}

The last support seen in the study was the support provided by the pupil's guardian. The student's response also shows a good status in all statements given; this can be seen in Table 7 in detail. $82.8 \%$ of students agreed that the student's guardian provided facilities to students follow the learning in the network. Another positive response is also given by students to the statement of the student's guardian assisting students in learning. A total of $74.3 \%$ of students agreed if the student's guardian helped the learning process. It is also supported by $77.2 \%$ of students agreeing that the student guardian reports to the teacher about the student's activities in online learning.

Table 7. Recapitulation of student response on student guardian sub-indicator support indicator

\begin{tabular}{|c|c|c|c|c|c|}
\hline $\begin{array}{c}\text { Sub } \\
\text { Indicator }\end{array}$ & Statement & SA & A & DA & SDA \\
\hline \multirow[t]{2}{*}{ Training } & $\begin{array}{l}\text { Student guardians } \\
\text { provide facilities for } \\
\text { students to follow } \\
\text { online learning }\end{array}$ & $17.1 \%$ & $65.7 \%$ & $17.1 \%$ & $0 \%$ \\
\hline & $\begin{array}{l}\text { Student guardians } \\
\text { take part in helping } \\
\text { students follow } \\
\text { online learning }\end{array}$ & $20 \%$ & $54.3 \%$ & $22.9 \%$ & $2.9 \%$ \\
\hline Facilities & $\begin{array}{l}\text { Student guardians } \\
\text { provide reports to } \\
\text { teachers about } \\
\text { student activities in } \\
\text { online learning }\end{array}$ & $14.3 \%$ & $62.9 \%$ & $22.9 \%$ & $0 \%$ \\
\hline
\end{tabular}

\section{DISCUSSION}

Today's world of education has been affected by the covid-19 pandemic, which resulted in no crowding because it is contagious, so teaching and learning activities are carried out online. Online learning or online, face-to-face meetings instead of face-to-face meetings for the delivery of material given to students through video content as one of the learning media [12]. The online learning process can affect students' motivation level in the following learning because of factors that influence online learning, according to [13]. The main barriers to online education are lack of technical resources, high costs, internet connectivity consistency, family financial crisis, and a heavy burden for students. The availability of internet networks in remote areas can make a big problem in online learning because it is difficult to access the web. These errors occur in the system, software updates, etc. Not all areas in Indonesia are strategic, meaning remote locations make it challenging to find a network. In this study, it was found that the internet connection mainly reflects the quality and clarity of a video that is audiovisual; some students consider it low but good enough for teachers [14].

Teachers must ensure that there is a need for interaction between teachers and students. There are no restrictions on them communicating with each other about teaching materials and evaluation through assignments. Although learning is done online, the interaction between teachers and students must go well 
so that there is no doubt in online learning. According to [15], Some classes are firmly established on teacherstudent and student-student interaction to enhance understanding of standing that content, with limited experience and training or without training, is impossible to achieve at the same level online. This study compares our research that social interaction between teachers and students with learning progress, learning distance is not as effective as face-to-face education. Students prefer face-to-face learning, so they can share understanding in learning more opportunities through face-to-face interactions [16]. Other studies assume that they have two points of view: the teacher's point of view and the student's point of view. From a teacher's point of view, they believe face-to-face learning can directly capture students' responses to know that students are listening to ongoing education or are thinking about something else.

In contrast, online learning teachers should often force students to answer. From students' point of view with online learning, it doesn't seem easy to concentrate and control the knowledge. It can be concluded that the quality of online education for students who have no intention and do not want to learn independently ensures they get things that may be worse than face-to-face learning [17].

Timely completion of schoolwork is a challenge to online learning due to the lack of supporting resources to complete schoolwork [18]. Other studies have suggested that students must share answers in writing to a discussion platform devoted to answering a series of questions to complete a given task. This granting model is given back the following week to compare answers between the initial week and the next week to further analyze the interconnected impact [19]. This research implies that not all regions experience a terrible signal in carrying out online learning to maximize the knowledge that is applied to the school.

\section{CONCLUSION}

Based on the exposure of the discussion above, we can see that the statement that gives the most positive response is the sub-indicator of interaction. Students are comfortable with the existence of teachers because they can interact directly when the learning process is carried out. This proves that students have not been able to maximize when there is a transfer of knowledge in online learning. In addition, support from the government and schools related to online learning is a determinant so that education can run optimally. The limitation of this research is that few students participate in filling out the questionnaires that have been distributed. It is hoped that the following analysis will use a larger sample and fewer statements in the questionnaire so that students focus more on filling it out.

\section{REFERENCES}

[1] V. B. Lemes et al., "Associations among psychological satisfaction in physical education, sports practice, and health indicators with physical activity: Direct and indirect ways in a structural equation model proposal," Int. J. Pediatr. Adolesc. Med., no. XXXX, 2020.

[2] M. Kirkham-King, T. A. Brusseau, J. C. Hannon, D. M. Castelli, K. Hilton, and R. D. Burns, "Elementary physical education: A focus on fitness activities and smaller class sizes are associated with higher levels of physical activity," Prev. Med. Reports, vol. 8, no. September, pp. 135-139, 2017.

[3] X. Zhan, C. C. T. Clark, R. Bao, M. Duncan, J. T. Hong, and S. T. Chen, "Association between physical education classes and physical activity among 187,386 adolescents aged 13-17 years from 50 low- and middle-income countries," J. Pediatr. (Rio. J)., no. xx, 2021.

[4] V. Balan, G. Marinescu, L. Ticala, and M. Shao, "Physical Education-Longlife Learning Factor," Procedia - Soc. Behav. Sci., vol. 46, pp. 1328-1332, 2012.

[5] H. Kalajas-Tilga, A. Koka, V. Hein, H. Tilga, and L. Raudsepp, "Motivational processes in physical education and objectively measured physical activity among adolescents," J. Sport Heal. Sci., vol. 9, no. 5, pp. 462-471, 2020.

[6] S. Chattopadhyay, L. Zary, C. Quek, and D. K. Prasad, "Motivation detection using EEG signal analysis by a residual-in-residual convolutional neural network," Expert Syst. Appl., vol. 184, no. July, p. 115548, 2021.

[7] M. B. Herlambang, N. A. Taatgen, and F. Cnossen, "Modeling motivation using goal competition in mental fatigue studies," J. Math. Psychol., vol. 102, p. 102540, 2021.

[8] V. Sieber, U. Grob, and A. Praetorius, "Teachers' motivational profiles and their longitudinal associations with teaching quality," Learn. Instr., no. July 2020, p. 101514, 2021.

[9] P. Moll-Khosrawi, J. S. Cronje, C. Zöllner, J. C. Kubitz, and L. Schulte-Uentrop, "Understanding how the motivational dimension of learning is influenced by clinical teaching in medical education: A prospective cohort study," Ann. Med. Surg., vol. 65, no. April 2021.

[10] T. Muthuprasad, S. Aiswarya, K. S. Aditya, and G. K. Jha, "Students' perception and preference for online education in India during COVID -19 pandemic," Soc. Sci. Humanity. Open, vol. 3, no. 1, p. 100101, 2021. 
[11] A. Saha, A. Dutta, and R. I. Sifat, "The mental impact of digital divide due to COVID-19 pandemic induced emergency online learning at undergraduate level : Evidence from undergraduate students from Dhaka City," J. Affect. Disord., vol. 294, no. February, pp. 170-179, 2021.

[12] O. Ozan and Y. Ozarslan, "Video lecture watching behaviors of learners in online courses," EMI. Educ. Media Int., vol. 53, no. 1, pp. 27-41, 2016.

[13] M. Al-Amin, A. Al Zubair, B. Deb, and M. Hasan, "Status of a tertiary level online class in Bangladesh: students' response on preparedness, participation and classroom activities," Heliyon, vol. 7, no. 1, p. e05943, 2021.

[14] F. Tuma, A. K. Nassar, M. K. Kamel, L. M. Knowlton, and N. K. Jawad, "Students and faculty perception of distance medical education outcomes in the resource-constrained system during COVID19 pandemic. A cross-sectional study," Ann. Med. Surg., vol. 62, no. January, pp. 377-382, 2021.

[15] L. Lorenza and D. Carter, "Emergency online teaching during COVID-19: A case study of Australian tertiary students in teacher education and creative arts," Int. J. Educ. Res. Open, vol. 2-2, no. February, p. 100057, 2021.

[16] I. Sani, Y. Hamza, Y. Chedid, J. Amalendran, and N. Hamza, "Understanding the consequence of COVID-19 on undergraduate medical education: Medical students' perspective," Ann. Med. Surg., vol. 58, no. September, pp. 117-119, 2020.

[17] J. Yu-Fong Chang, L.-H. Wang, T.-C. Lin, F.-C. Cheng, and C.-P. Chiang, "Comparison of learning effectiveness between the physical classroom and online learning for dental education during the COVID-19 pandemic," J. Dent. Sci., no. XXXX, 2021.

[18] A. P. A. Hermida, "College students' use and acceptance of emergency online learning due to COVID-19," Int. J. Educ. Res. Open, vol. 1, no. July, p. 100011, 2020.

[19] J. J. Salovaara, J. Pietikäinen, and H. Cantell, "Perceptions of interconnected sustainability: Students' narratives bridging transition and education," J. Clean. Prod., vol. 281, 2021. 